\title{
Diabetes Melitus dan Tingkat Keparahan Jaringan Periodontal
}

\author{
Diabetes Melitus and Severity of Periodontal Tissue
}

\author{
Rikawarastuti, Eka Anggreni, Ngatemi
}

\section{Jurusan Keperawatan Gigi Politeknik Kesehatan Kementerian Kesehatan Jakarta I}

\begin{abstract}
Abstrak
Penyakit periodontal merupakan masalah kesehatan gigi dan mulut dengan prevalensi cukup tinggi di Indonesia (60\%). Diabetes melitus merupakan salah satu faktor predisposisi terjadinya penyakit periodontal. Tujuan penelitian adalah menganalisis hubungan diabetes melitus terhadap tingkat keparahan jaringan periodontal. Jenis penelitian observasional analitik potong lintang. Penelitian dilakukan di Puskesmas Kecamatan Jagakarsa Jakarta Selatan pada bulan Oktober - November 2014 dengan populasi penelitian adalah pengunjung Puskesmas Kecamatan Jagakarsa. Pengambilan sampel menggunakan simple random sampling sebanyak 122 orang. Status diabetes melitus didapat dari rekam medis poli penyakit tidak menular. Analisis data menggunakan kai kuadrat dan regresi logistik sederhana. Hasil penelitian menunjukkan proporsi penderita diabetes melitus usia > 50 tahun mengalami kerusakan jaringan periodontal yang lebih parah dibandingkan penderita diabetes melitus $\leq 50$ tahun. Kelompok diabetes melitus berisiko 3,5 kali mengalami keparahan jaringan periodontal dibandingkan kelompok nondiabetes melitus, $\mathrm{OR}=3,505$ (1,609-7,634), nilai $p=0,002$. Kelompok diabetes melitus tidak terkendali berisiko 2,5 kali mengalami keparahan jaringan periodontal dibandingkan kelompok diabetes melitus terkendali, nilai $O R=2,514(0,892-7,085)$, nilai $p=0,12$ disebabkan ukuran sampel terlalu kecil. Penderita diabetes melitus lebih berisiko mengalami keparahan jaringan periodontal dibandingkan dengan nondiabetes melitus. Pada diabetes melitus tidak terkendali, risiko penyakit periodontal semakin tinggi.

Kata kunci: Diabetes melitus, jaringan periodontal, tingkat keparahan
\end{abstract}

\section{Abstract}

Periodontal disease is a teeth and oral health problem, with a quite high prevalence in Indonesia (66\%). Diabetes mellitus one of predisposing factors of periodontal occurence. This study aimed to analyze relation between diabetes mellitus and the severity of periodontal tissue. The study was observational analytic study with cross-sectional design. The study was con- ducted in Jagakarsa District Primary Health Care of South Jakarta on October to November 2014 with the primary health care visitors as population. Sample was taken using simple random sampling as much as 122 respondents. Diabetes mellitus status was identified from the non-infectious disease medical record. Data analysis used chi-square and simple logistic regression. Results showed proportion of diabetes mellitus patients $>50$ years suffered periodontal tissue damage more severe than $\leq 50$ years old patients. Diabetes mellitus group had 3.5 times risk of suffering severe periodontal tissue than nondiabetes mellitus group, OR $=3.505$ (1.6097.634 ), $p$ value $=0.002$. Uncontrolled diabetes mellitus group had 2.5 times risk of suffering severe periodontal tissue than controlled diabetes mellitus group, $\mathrm{OR}=2.514(0.892-7.085)$, $\mathrm{p}$ value $=0.12$ due too small size of sample. Diabetes mellitus sample patients were more risky to suffer severe periodontal tissue than nondiabetes mellitus patients. On uncontrolled diabetes mellitus, the risk of periodontal disease was getting higher.

Keywords: Diabetes mellitus, periodontal tissue, severity

\section{Pendahuluan}

Diabetes melitus menjadi salah satu masalah kesehatan yang besar. Data dari studi global menunjukkan bahwa jumlah penderita diabetes melitus pada tahun 2011 telah mencapai 366 juta orang, dan diperkirakan akan meningkat menjadi 552 juta pada tahun 2030.1 Proporsi penduduk Indonesia yang berusia $\geq 15$ tahun dengan diabetes melitus tahun 2013 sebesar $6,9 \%$ yang tersebar di perkotaan $(7 \%)$ dan pedesaan $(6,8 \%)$ serta lebih banyak terjadi pada perempuan $(7,7 \%)$ dibandingkan laki-laki $(5,6 \%){ }^{2}$

Korespondensi: Rikawarastuti, Jurusan Keperawatan Gigi Poltekkes Kemenkes Jakarta I, Jl. Lebak Bulus III No 1 Cilandak Jakarta Selatan, No.Telp. 02175909605,e-mail: rikawarastuti@gmail.com 
Faktor-faktor yang berhubungan dengan komplikasi diabetes melitus adalah usia, jenis kelamin, obesitas, merokok, dan aktivitas fisik. Faktor utama yang berhubungan adalah merokok. ${ }^{3}$ Salah satu komplikasi diabetes melitus di bidang kedokteran gigi adalah oral diabetic meliputi mulut kering, gusi mudah berdarah (gingivitis), kalkulus, resorbsi tulang alveolaris, dan periodontitis. Periodontitis merupakan komplikasi yang paling sering terjadi pada penderita diabetes melitus dengan tingkat prevalensi yang tinggi hingga mencapai angka $75 \% .^{4}$

Riset kesehatan daerah (Riskesdas) tahun 2013 menyatakan bahwa prevalensi nasional masalah gigi mulut adalah $25,9 \%$, tetapi hanya $8,1 \%$ yang menerima perawatan atau pengobatan. ${ }^{2}$ Menurut Survei Kesehatan Rumah Tangga (SKRT) pada 2011, prevalensi penyakit periodontal mencapai $60 \%$ pada masyarakat di Indonesia. 5

Penyakit periodontal yang biasa dijumpai yaitu gingivitis dan periodontitis. Gingivitis adalah bentuk penyakit periodontal yang ringan dengan tanda klinis gingiva berwarna merah, membengkak, dan mudah berdarah tanpa ditemukan kerusakan tulang alveolar. Periodontitis adalah suatu penyakit peradangan jaringan pendukung gigi yang disebabkan oleh kelompok mikroorganisme tertentu yang biasanya berasal dari plak gigi yang dapat mengakibatkan penghancuran progresif jaringan ikat periodontal dan tulang alveolar dengan pembentukan saku, resesi, atau keduanya. Infeksi periodontal dimulai oleh invasi oral patogen yang berkolonisasi pada biofilm plak gigi di permukaan akar gigi. 6

Penelitian ini bertujuan menganalisis hubungan diabetes melitus terhadap tingkat keparahan jaringan periodontal pada usia $\geq 30$ tahun. Penelitian dilakukan di Puskesmas Kecamatan Jagakarsa, Jakarta Selatan. Pemilihan tempat berdasarkan hasil survei awal yang dilakukan di Puskesmas Kecamatan Jagakarsa karena setiap hari Rabu menjadi hari khusus pemeriksaan penderita diabetes melitus di poliklinik penyakit tidak menular dengan rata-rata pasien lebih dari 50 pasien setiap hari.

\section{Metode}

Penelitian dilakukan di Puskesmas Kecamatan Jagakarsa. Penelitian ini bersifat observasional analitik dengan desain potong lintang. Data yang diperoleh merupakan data gabungan yakni data primer untuk mengukur tingkat keparahan jaringan periodontal serta data sekunder untuk data karakteristik responden dan kadar glukosa darah responden.

Populasi penelitian adalah pengunjung Puskesmas Kecamatan Jagakarsa. Sampel dihitung menggunakan rumus besar sampel untuk hipotesis dua proporsi populasi
$(\mathrm{P} 1=0,5$ dan $\mathrm{P} 2=0,6)$. Jumlah sampel minimal pada dua kelompok menjadi 80 responden. Berdasarkan survei awal, jumlah penderita diabetes melitus yang melakukan kontrol penyakit diabetes melitus di Puskesmas Kecamatan Jagakarsa cukup banyak sehingga sampai pengambilan sampel terakhir diperoleh sampel 122 orang.

Peneliti mengumpulkan sampel dari pengunjung poli umum dan poli gigi (kelompok nondiabetes melitus) dan sampel dari pengunjung poli penyakit tidak menular (kelompok diabetes melitus) di Puskesmas Kecamatan Jagakarsa. Kelompok diabetes melitus diperoleh melalui rekam medis sebagai pasien yang rutin memeriksa status penyakit diabetes melitus. Pengambilan sampel dilakukan dengan simple random sampling. Kriteria inklusi dalam penelitian ini adalah pengunjung puskesmas berusia $\geq 30$ tahun, mengisi formulir informed consent, masih memiliki gigi yang dibutuhkan untuk pengukuran, tidak memiliki riwayat atau tidak sedang dalam terapi radiasi. Sedangkan kriteria eksklusi adalah pengunjung yang berusia $<30$ tahun dan tidak bersedia menjadi subjek penelitian. Subjek yang bersedia menjadi responden menandatangani informed consent.

Instrumen pada penelitian ini adalah kuesioner untuk mengumpulkan data karakteristik yang meliputi usia, jenis kelamin serta berat badan dan tinggi badan untuk menghitung indeks massa tubuh. Bagi penderita diabetes melitus ditambahkan data meliputi gula darah puasa (GDP), gula darah dua jam postprandial / setelah makan (GD2jamPP), lama menderita diabetes melitus, keturunan diabetes melitus, dan komplikasi penyakit lain. Status diabetes melitus terkendali diperoleh berdasarkan tabel pengendalian diabetes melitus menurut Perkumpulan Endokrinologi Indonesia (PERKENI) ${ }^{7}$ yakni pemeriksaan GDP $<125 \mathrm{mg} / \mathrm{dL}$ dan GD2jamPP $<$ $200 \mathrm{mg} / \mathrm{dL}$ terkendali sedang, GDP $\geq 125 \mathrm{mg} / \mathrm{dL}$ dan GD2jamPP $\geq 200 \mathrm{mg} / \mathrm{dL}$ tidak terkendali. Seluruh responden diperiksa kondisi jaringan periodontal menggunakan kaca mulut dan periodontal probe World Health Organization (WHO) dengan pengukuran probing periodontal depth dan bleeding on probing pada seluruh gigi yang tersisa. Peneliti memeriksa status gingival dan status jaringan periodontal pada enam sekstan untuk mendapatkan status keparahan penyakit periodontal. Sistem yang dinilai pada komponen penyakit periodontal yaitu skor gingiva dan skor periodontal (kedalaman poket). Jaringan periodontal dinyatakan parah jika saku gusi minimal > 4 milimeter sampai dengan copot, serta tidak parah jika kondisi gigi sehat/berdarah/karang gigi/saku gusi $<4$ milimeter. ${ }^{6}$ Analisis data menggunakan kai kuadrat dan regresi logistik sederhana.

\section{Hasil}

Berdasarkan hasil penelitian, diperoleh karakteristik 
Tabel 1. Karakteristik Responden

\begin{tabular}{|c|c|c|c|c|c|c|c|}
\hline \multirow{3}{*}{ Variabel } & \multirow{3}{*}{ Kategori } & \multicolumn{4}{|c|}{ Jumlah Responden } & & \\
\hline & & \multicolumn{2}{|c|}{ DM } & \multicolumn{2}{|c|}{ Tidak DM } & \multicolumn{2}{|c|}{ Total } \\
\hline & & $\mathbf{n}$ & $\%$ & $\mathbf{n}$ & $\%$ & n & $\%$ \\
\hline \multirow[t]{3}{*}{ Usia (tahun) } & $30-40$ & 5 & 17,90 & 23 & 82,1 & 28 & 23,00 \\
\hline & $41-50$ & 17 & 40,50 & 25 & 59,5 & 42 & 34,40 \\
\hline & $>50$ & 40 & 76,90 & 12 & 23,1 & 52 & 42,60 \\
\hline \multirow{2}{*}{ Jenis kelamin } & Laki-laki & 16 & 61,50 & 10 & 38,5 & 26 & 21,30 \\
\hline & Perempuan & 46 & 47,90 & 50 & 52,1 & 96 & 78,70 \\
\hline \multirow[t]{3}{*}{ Indeks massa tubuh } & Kurang & 3 & 75,00 & 1 & 25,0 & 4 & 3,30 \\
\hline & Normal & 26 & 44,10 & 33 & 55,9 & 59 & 48,40 \\
\hline & Lebih & 33 & 55,90 & 26 & 44,1 & 59 & 48,40 \\
\hline \multirow[t]{2}{*}{ Gula darah puasa (mg/dL) } & $<125$ & 26 & 41,94 & - & - & 26 & 41,94 \\
\hline & $\geq 125$ & 36 & 58,06 & - & - & 36 & 58,06 \\
\hline \multirow[t]{2}{*}{ Gula darah 2 jam postprandial (mg/dL) } & $<179$ & 28 & 45,16 & - & - & 28 & 45,16 \\
\hline & $\geq 180$ & 34 & 54,84 & - & - & 34 & 54,84 \\
\hline \multirow[t]{2}{*}{ Lama menderita diabetes melitus } & $\leq 5$ tahun & 49 & 79,03 & - & - & 49 & 79,03 \\
\hline & $>5$ tahun & 13 & 20,97 & - & - & 13 & 20,97 \\
\hline \multirow[t]{2}{*}{ Komplikasi penyakit lain } & Tidak ada & 14 & 22,58 & - & - & 14 & 22,58 \\
\hline & Ada & 48 & 77,42 & - & - & 48 & 77,42 \\
\hline \multirow[t]{2}{*}{ Keturunan } & Tidak ada & 29 & 46,77 & - & - & 29 & 46,77 \\
\hline & Ada & 33 & 53,23 & - & - & 33 & 53,23 \\
\hline
\end{tabular}

Tabel 2. Hubungan antara Karakteristik Responden dengan Tingkat Keparahan Jaringan Periodontal

\begin{tabular}{|c|c|c|c|c|c|c|c|}
\hline \multirow{3}{*}{ Variabel } & \multirow{3}{*}{ Kategori } & \multicolumn{4}{|c|}{ Tingkat Keparahan } & \multirow{3}{*}{ OR } & \multirow{3}{*}{ Nilai $p$} \\
\hline & & \multicolumn{2}{|c|}{ Parah } & \multicolumn{2}{|c|}{ Tidak Parah } & & \\
\hline & & n & $\%$ & n & $\%$ & & \\
\hline \multirow[t]{3}{*}{ Usia (tahun) } & $30-40$ & 3 & 10,7 & 25 & 89,3 & $0,079(0,021-0,299)$ & 0,004 \\
\hline & $41-50$ & 12 & 28,6 & 30 & 71,4 & $0,274(0,114-0,658)$ & \\
\hline & $>50$ & 31 & 59,6 & 21 & 40,4 & 1,000 & \\
\hline \multirow[t]{2}{*}{ Jenis kelamin } & Laki-laki & 10 & 38,5 & 16 & 61,5 & $0,960(0,394-2,341)$ & 1,000 \\
\hline & Perempuan & 36 & 37,5 & 60 & 62,5 & 1,000 & \\
\hline \multirow[t]{3}{*}{ Indeks massa tubuh } & Kurang & 2 & 50,0 & 2 & 50,0 & $1,690(0,197-14,538)$ & 0,633 \\
\hline & Normal & 25 & 42,4 & 34 & 57,6 & $1,659(0,724-3,801)$ & \\
\hline & Lebih & 19 & 32,2 & 40 & 67,8 & & \\
\hline
\end{tabular}

Tabel 3. Hubungan antara Kelompok dengan Tingkat Keparahan Jaringan Periodontal

\begin{tabular}{|c|c|c|c|c|c|c|}
\hline \multirow{3}{*}{ Status DM } & \multicolumn{4}{|c|}{ Tingkat Keparahan Jaringan Periodontal } & \multirow{3}{*}{ OR } & \multirow{3}{*}{ Nilai $p$} \\
\hline & \multicolumn{2}{|c|}{ Parah } & \multicolumn{2}{|c|}{ Tidak Parah } & & \\
\hline & $\mathbf{n}$ & $\%$ & $\mathbf{n}$ & $\%$ & & \\
\hline DM & 32 & 51,6 & 30 & 48,4 & $3,505(1,609-7,634)$ & 0,002 \\
\hline Tidak DM & 14 & 23,3 & 46 & 76,7 & & \\
\hline
\end{tabular}

sosiodemografi responden penelitian (Tabel 1). Hasil analisis bivariat antara karakteristik responden terhadap tingkat keparahan jaringan periodontal menunjukkan adanya hubungan yang bermakna antara usia dan tingkat keparahan jaringan periodontal (Tabel 2).

Responden kelompok diabetes melitus berisiko 3,505 kali mengalami keparahan jaringan periodontal dibandingkan dengan kelompok nondiabetes melitus (Tabel $3)$. Responden kelompok diabetes melitus tidak terkendali berisiko 2,514 kali mengalami keparahan jaringan periodontal dibandingkan dengan kelompok diabetes melitus terkendali (Tabel 4).

\section{Pembahasan}

Diabetes melitus merupakan penyakit metabolik akibat resistensi insulin dan berhubungan dengan kesehatan jaringan periodontal. Bila penyakit ini berlanjut terus dan tidak segera dirawat, lama kelamaan akan menyebabkan gigi goyang bahkan lepas dengan sendirinya. ${ }^{8}$ Responden penelitian pada kelompok diabetes melitus yang berusia 
Tabel 4. Hubungan Pengendalian Diabetes Melitus dengan Tingkat Keparahan Jaringan Periodontal

\begin{tabular}{lccccccc}
\hline \multirow{2}{*}{ Status DM } & \multicolumn{2}{c}{ Tingkat Keparahan Jaringan Periodontal } & & \\
\cline { 2 - 5 } & \multicolumn{2}{c}{ Parah } & & \multicolumn{2}{c}{ Tidak Parah } & OR & Nilai p \\
\cline { 2 - 6 } & $\mathbf{n}$ & $\%$ & $\mathbf{n}$ & $\%$ & & \\
\hline DM tidak terkendali & 22 & 61,1 & 14 & 38,9 & $2,514(0,892-7,085)$ & 0,12 \\
DM terkendali & 10 & 38,5 & 16 & 61,5 & & \\
\hline
\end{tabular}

$>50$ tahun banyak mengalami gigi copot sendiri akibat penyakit diabetes melitus yang diderita.

Responden penelitian ini paling banyak pada usia > 50 tahun, didominasi perempuan dan mayoritas sudah mengetahui dirinya menderita diabetes melitus paling lama lima tahun. Penyakit periodontal lebih banyak dijumpai pada orangtua daripada kelompok yang muda, keadaan ini sering dikaitkan sebagai akibat kerusakan jaringan yang kumulatif selama hidup (proses penuaan), kerentanan infeksi oral, respons inflamasi berlebihan, dan kerusakan tulang alveolar. ${ }^{9}$ Sedangkan hubungan faktor jenis kelamin dengan keparahan jaringan periodontal masih diragukan, ada yang mengatakan bahwa kondisi periodontal perempuan lebih baik daripada lakilaki dan sebaliknya.

Melihat hubungan antara usia, jenis kelamin, dan indeks massa tubuh dengan tingkat keparahan jaringan periodontal, maka hanya diperoleh hubungan yang bermakna pada variabel usia (nilai $\mathrm{p}=0,004$ ). Adanya hubungan antara usia dan tingkat keparahan jaringan periodontal sejalan dengan penelitian di Chicago, Amerika Serikat tahun 2010 yang menunjukkan prevalensi penyakit periodontal mengalami peningkatan pada usia lanjut, yaitu $70,1 \% .{ }^{10}$ Kerusakan jaringan periodontal meningkat sejalan dengan bertambahnya usia. Perubahan yang terjadi pada usia lanjut mengakibatkan menurunnya daya tahan jaringan periodontal terhadap pelbagai iritasi, terutama bakteri plak. Perkembangan penyakit periodontal dipengaruhi oleh pelbagai faktor seperti mikroorganisme, respons penjamu, latar belakang sistemik, dan genetik dari penjamu. ${ }^{11}$

Berdasarkan hasil penelitian ini, ditemukan mayoritas responden kelompok diabetes melitus $(77,42 \%)$ memiliki komplikasi penyakit lain terutama hipertensi. Selain itu, ada yang mengidap penyakit jantung, asam urat, atau kombinasi di antaranya. Hal ini sejalan dengan penelitian yang menunjukkan bahwa orang yang memiliki riwayat hipertensi berisiko dua kali mengalami diabetes melitus tipe 2 dibandingkan dengan orang yang tidak memiliki riwayat hipertensi meskipun secara statistik tidak bermakna. ${ }^{12}$

Responden kelompok diabetes melitus (53,33\%) memiliki riwayat keturunan diabetes melitus. Hasil ini tidak berbeda jauh dengan pendapat Tandra, ${ }^{12}$ yang menyatakan bahwa $50 \%$ pasien diabetes tipe 2 mempunyai orangtua yang menderita diabetes, dan lebih sepertiga pasien diabetes memiliki saudara yang mengidap diabetes.

Diabetes melitus memiliki hubungan signifikan dengan tingkat keparahan jaringan periodontal (nilai $\mathrm{p}=$ 0,002). Kelompok diabetes melitus lebih berisiko 3,505 kali mengalami keparahan jaringan periodontal dibandingkan dengan kelompok nondiabetes melitus. Hal tersebut ditunjukkan secara signifikan melalui indeks gingiva yang lebih tinggi, kedalaman poket periodontal $>4$ milimeter, tingkat perlekatan klinis, dan bahkan gigi responden menjadi copot sendiri akibat diabetes melitus. Demikian juga dengan penelitian yang dilakukan pada pasien rawat jalan klinik penyakit dalam di dua rumah sakit utama di Yordania terhadap status periodontal. Dari 106 pasien diabetes tipe 2 dibandingkan dengan 106 pasien nondiabetes menunjukkan penyakit periodontal lebih parah pada pasien diabetes tipe 2 dibandingkan pasien nondiabetes. Tidak terdapat perbedaan yang signifikan pada indeks plak rata-rata antara penderita diabetes dan nondiabetes. Tingkat keparahan penyakit periodontal secara signifikan lebih tinggi pada pasien dengan diabetes $>5$ tahun dibandingkan $\leq 5$ tahun. ${ }^{13}$

Diabetes melitus tidak terkendali memiliki hubungan signifikan dengan tingkat keparahan jaringan periodontal ditunjukkan dengan nilai $\mathrm{OR}=2,514(0,892-7,085)$ dengan nilai $p=0,12$. Artinya, kelompok diabetes melitus yang tidak terkendali berisiko 2,514 kali mengalami keparahan jaringan periodontal dibandingkan dengan kelompok diabetes melitus terkendali meskipun tidak bermakna secara statistik. Penelitian lain juga percaya bahwa penyakit periodontal pada pasien diabetes dikaitkan dengan adanya komplikasi diabetes kronis. Tingkat kerusakan periodontal pada pasien diabetes dipengaruhi oleh kontrol glikemik dan kapasitas imunitas individu. ${ }^{14}$

\section{Kesimpulan}

Penderita diabetes melitus lebih berisiko mengalami keparahan jaringan periodontal dibandingkan dengan nondiabetes melitus. Sedangkan kelompok diabetes melitus tidak terkendali memiliki risiko yang lebih tinggi jika dibandingkan dengan kelompok diabetes melitus ter- 
kendali.

\section{Saran}

Penderita diabetes melitus selalu mengupayakan pengendalian kadar gula darah agar dapat mencegah terjadinya keparahan jaringan periodontal. Untuk penelitian lebih lanjut, dapat memperbesar ukuran sampel agar dapat dilihat lebih tegas kemaknaan antara diabetes melitus terkendali dengan tingkat keparahan jaringan periodontal.

\section{Daftar Pustaka}

1. Trisnawati SK, Setyorogo S. Faktor risiko kejadian diabetes mellitus tipe 2 di Puskesmas Kecamatan Cengkareng Jakarta Barat tahun 2012. Jurnal Ilmiah Kesehatan. 2013 ; 3 (1): 6-11.

2. Badan Penelitian dan Pengembangan Kesehatan Kementerian Kesehatan Republik Indonesia. Riset kesehatan dasar tahun 2013. Jakarta: Kementerian Kesehatan Republik Indonesia; 2013.

3. Rosyada A, Trihandini I. Determinan komplikasi kronik diabetes meli tus pada lanjut usia. Kesmas Jurnal Kesehatan Masyarakat Nasional. 2013; 7 (9): 395-401.

4. Sri H. Analisis faktor yang berhubungan dengan tingkat keparahan periodontitis pada penderita DM tipe 2 di Poli Diabetes RSU dr. Soetomo Surabaya. Buletin Penelitian RSU dr. Soetomo. 2008; 10 (2): 10- 2 .

5. Kementerian Kesehatan Republik Indonesia. Survei kesehatan rumah tangga tahun 2011. Jakarta: Kementerian Kesehatan Republik Indonesia; 2011.

6. Carranza FA. Newman MG. Takei HH, Klokkevold PR. Carranza's clin ical periodontology. 10th ed. Missouri: Saunders Elsevier; 2006 .

7. Perkumpulan Endrokinologi Indonesia. Konsensus pengelolaan dan pencegahan diabetes mellitus tipe 2 di Indonesia. Jakarta: Perkumpulan Endrokenologi Indonesia ; 2006

8. Rose LF, Mealey BL. Periodontics: medicine, surgery, and implants. Saint Louis: Elsevier Mosby; 2004

9. Casarin RCV, Barbagallo A. Meulman T, Santos VR, Sallum EA, Nociti FH, et al. Subgingival biodiversity in subjects with uncontrolled type-2 diabetes and chronic periodontitis. Journal of Periodontal Research. 2013; 48 (1): 30-6.

10. Thornton E, Genco RJ. Prevalence of periodontitis in adults in the united states: 2009 and 2010. Journal of Dental Research [serial on internet]. 2012 [cited 2013 March 22]; 91 (10): 913-20. Available from: http://www.perio.org/consumer/cdc-study.htm.

11. Wilkins EM. Clinical practice of the dental hygienist. $10^{\text {th }}$ ed. Lippincott: Williams \& Wilkins cop; 2009.

12. Tandra H. Segala sesuatu yang harus anda ketahui tentang diabetes. Jakarta: PT. Gramedia Pustaka Utama; 2008.

13. Khader YS, Albashaireh ZS, Hammad MM. Periodontal status of type 2 diabetics compared with nondiabetics in north Jordan. Eastern Mediterrenean Health Journal. 2008 May-June; 14 (3): 654-61.

14. Hussain AM. The relationship between diabetes mellitus and periodontitis. Al Ameen Journal of Medical Science. 2011; 4 (1): 84-6. 